\title{
A Nation of Tribes and Priests \\ The Jews and the Immorality of the Caste System
}

\author{
Jakob De Roover, Ghent University, Belgium
}

Published in: Western Foundations of the Caste System, eds. Martin Fárek, Dunkin Jalki, Sufiya Pathan, and Prakash Shah, 173-220. Basingstoke: Palgrave Macmillan.

In the currently dominant discourse about Indian society, the caste system appears as an immoral social structure. This moral dimension is perhaps most visible in political and popular rhetoric. Award-winning author Arundhati Roy (2014) calls the caste system "one of the most brutal modes of hierarchical social organisation that human society has known." A report published in the UK, titled The Evil of Caste, denounces the system as "the largest systemic violation of human rights in today's world" (Chahal 2008, 1). The same type of judgement is present in academic scholarship also. By deploying the caste hierarchy, one scholar writes, "Brahmins did not articulate 'human rights' but 'caste rights', which had the side effect that, in the course of time, about one-fifth of the total population, as 'outcastes', had virtually no rights. They were treated worse than cattle, which even in legal theory ranked above them" (Klostermaier 2007, 296-7). Or in the words of another scholar: "Untouchables ... were dehumanized by the caste Hindu order" (Rao 2010, 1).

Importantly, the claim made by these authors is not simply that Indian society, like other societies, is home to unethical practices that need to be discarded, say, discrimination or violence against particular groups. To appreciate what is being said, it is important to distinguish between two dimensions of the dominant discourse about caste - a factual and a moral dimension. The first concerns the empirical properties attributed to the system: the Hindus are divided into a variety of castes and sub-castes; caste forms a hierarchical social organization; Brahmins traditionally occupy the highest position in the caste hierarchy and possess certain privileges; endogamy and commensality play major roles in the interaction between different castes, as do practices of untouchability and concerns about purity and pollution.

From these factual claims, descriptions of the caste system easily move to moral judgements. They do so by highlighting certain practices as blatant instances of caste discrimination: members of some castes cannot take water from the same wells or drink from the same cup as other castes; often, they are not allowed to enter the homes and temples of the latter. Untouchable castes have to live in separate quarters in a village and keep a physical distance from upper-caste members. Caste membership decides issues like who is an acceptable partner for marriage or which persons can have 
food together. According to these descriptions, anyone who defies the customs of caste is subject to violent reprisals: expulsion from one's caste, general ostracism, degrading treatment, and physical violence.

When authors identify such practices as reprehensible behaviour, they do something more. According to them, the practices instantiate the recurring patterns of interaction that characterize caste as a social system. The relevant practices are manifestations of the structure that attributes a superior position to certain castes and an inferior one to others. Moreover, these authors suggest, the fact that deviant behaviour is punished so severely shows that it is understood as a violation of something. Of what? Since there is no political or religious authority that imposes explicit caste laws, it must concern violation of a different kind of rule: the kind that states moral obligations. In other words, according to the dominant discourse about caste, these odious practices must be manifestations of the principles that constitute the caste system.

As Balagangadhara $(2012,104)$ argues, this discourse implies that "the caste system is an immoral social order twice over: not only does the practice of caste discrimination violate certain moral norms, but also, as a social order, it makes immorality obligatory." Caste is a brutal mode of hierarchical social organisation because its rules compel people to act in inhumane ways. This is the moral dimension of the dominant discourse about the caste system: it is viewed as a social organization that transforms immorality into a duty by representing its practices as moral obligations, even though they are immoral.

This characterization of the caste system is inherently implausible, Balagangadhara points out. On the one hand, it transforms the large majority of Indians - all those who have not explicitly and unfailingly renounced the caste system - into immoral beings bound to discriminate and dehumanize. On the other hand, it implies that the same people show a moral integrity of a perverse kind. They are immoral "not because they violate moral obligations but because the obligations which they obey are immoral in nature" $(2012,108)$. That is, it is their desire and capacity to be moral by consistently living up to one's duties that transforms them into immoral beings. Thus, these descriptions carry two contradictory messages: the meta-level message suggests that Indians are rational and moral by consistently following a set of rules or principles; the object-level message says just the opposite, since the same people systematically engage in immoral and irrational behaviour (Balagangadhara 2012, 109).

According to the textbook story about caste, then, generation after generation of Hindus lived by unethical rules and raised their children to do the same. Even worse, they did so in the face of a variety of movements that revealed the injustice of this system and aimed to abolish it, from Buddhism and the Bhakti traditions to the British missionaries. The same story suggests that it is 
only because this message eventually penetrated the minds of educated Indians that the postIndependence state implemented legislation that abolishes untouchability, penalizes caste discrimination, and aims to set right the historic injustices of caste. Still, commentators lament, these laws have had little impact on the attitudes of the average Indian: caste violence and discrimination thrive in contemporary India (see Jalki and Pathan, this volume). Consequently, the Indian people must show a stubborn insistence to live by this system of obligations and prohibitions, even after receiving recurrent proof of its immorality.

If this textbook story is correct, the caste system must have an extraordinary capacity: as a social structure, it is able to blind the men and women living under its spell to such an extent that they cannot see what everyone else appears to see so easily. To those who are not part of the caste system, it appears to be self-evidently immoral; in contrast, those who live in its confines remain blind to its immorality and continue to follow its rules. How did this implausible conception of the caste system come into being? How could it be reproduced for centuries as though it constitutes a veridical description of Indian society? One thing is clear: since this conception of caste implies that 'insiders' cannot see the true nature of the caste system, it must necessarily be the result of the observations of 'outsiders'.

Because of Balagangadhara's work $(1994,2012)$, we are aware today that the dominant representations of Indian culture and society emerged within the framework of Western culture and tell us more about the constraints of the Western experience than they do about India. Thus, we know where to seek answers. This chapter will do so by focussing on the emergence of the factual and moral structures that are attributed to the caste system today. That is, it aims to take some steps forward by examining the different elements that coalesced into the dominant conception of caste as an immoral social system.

The first section looks at the crystallization of the idea that the Indian subcontinent was populated by a nation divided into a hierarchy of four tribes and united by a common religion. Surprisingly, this description appears to have mapped the Indian people and culture onto the structure of the Jewish nation described in the Old Testament. The second section examines the moral dimension of the discourse about caste. The belief that India was home to an idolatrous nation inevitably led to negative judgements about some of the practices and customs found there. Both Catholic and Protestant authors condemned the Brahmins as a self-interested and deceitful priesthood. However, for many decades, such descriptions went together with ambiguous statements about the morality of Hindu society and its division into castes.

The third section raises a central question: if earlier authors wrote about the moral status of caste in different ways, which change in conditions accounts for the crystallization and consolidation 
of the conception of caste as an immoral social system? The causes behind this shift, I suggest, lie neither in increasing knowledge about Indian society nor in some general process of moral progress, but in a very different factor: the impact of the Protestant Reformation on Western culture and its understanding of other cultures. As a result of an internal shift in the Protestant views of India, the conception of caste acquired a more systematic and coherent structure than it had known before. It became "the system of caste," an institution that merged religion and civil law and presented the rules of caste as religious obligations. In the concluding section, I raise some questions for future research that emerge from the discovery that today's moral discourse about the caste system is almost identical in structure to that developed by Christian missionaries in the nineteenth century.

\section{The Facts of a Heathen Nation}

Most observers today would agree that caste in India constitutes a hierarchical system, which traditionally organizes the social life of the Hindus and the many castes into which they are divided. This is the minimal factual structure attributed to the caste system, without which there would be no system to speak of. It is only in the course of the seventeenth century that this particular way of ordering the European observations of Indian society emerged in travel accounts and missionary reports: the notion crystallized that one 'Gentile' or 'heathen' nation populated India, which was divided into four general tribes or lineages, subdivided into many clans, and held together by an institution that ranked these tribes according to nobility and purity.

Did this notion emerge as the result of more accurate observations and the accumulation of empirical data about Indian society? This is implausible. For one, it ignores the conceptual problems that we still face in understanding the Hindus as a nation united by a common religion and caste hierarchy. From the nineteenth century onwards, the study of Indian society would produce more and more anomalies that undermined this account. During the colonial census, attempts to categorize the various groups of 'Hindus' according to a caste hierarchy revealed that it was impossible to do so in any coherent way (Blunt 1931, 8-9; Dirks 2002, 49, 202-212; Strachey 1911, 328-30). Consequently, the account could hardly be the result of the accumulation of information. Moreover, such ordered descriptions always depend on the concepts available to the describer. That is, when early modern European observers described the people of India as a nation consisting of a number of tribes or lineages organized into a hierarchy, they drew upon a particular set of conceptual resources, including notions like nation, tribe, and heathen religion.

Consider the observations made by two very different European travellers to India: the Italian adventurer and Catholic nobleman Pietro Della Valle, who travelled through the south of India in the 1620s, and the Dutch East India Company translator and Calvinist cleric Abraham Rogerius who 
stayed on the Coromandel coast in the first half of the seventeenth century. Della Valle wrote as follows:

The whole Gentile-people of India is divided into many sects or parties of men, known and distinguisht by descent or pedigree, as the Tribes of the Jews sometimes were; yet they inhabit the Country promiscuously mingled together, in every City and Land several Races one with another. 'Tis reckon'd that they are in all eighty four; some say more, making a more exact and subtle division. Every one of these hath a particular name, and also a special office and Employment in the Commonwealth, from which none of the descendants of that Race ever swerve ... . (Grey 1892, 77-8)

All these "tribes" or "races," Della Valle suggested, were derived by minute subdivision from the four principal ones, namely "the Brachmans, the Souldiers, the Merchants and the Artificers." The Brahmins are held the noblest and purest, "because their employment is nothing else but the Divine Worship, the service of Temples and Learning, and because they observe their own Religion with more rigor then any others." Again, he compared this to Judaism: he pointed out that the Brahmins among the Indians much resemble the Levites of the Jews. They too are divided into several sorts, with gradations of nobility, which also make them more rigorous in manner of eating and in superstitious ceremonies. They are astrologers, scholars, physicians, and secretaries, "but the most esteem'd and most sublime amongst the Brachmans, and consequently the most rigorous of all in point of eating and other observances, are those who perform the Office of Priests, whom they call Boti" (Grey 1892, 80).

In a work titled The Open Door to Hidden Heathendom (1651), Rogerius wrote in very similar terms about the people he encountered on the Coromandel coast. He presented them as "a heathen nation" consisting of four general tribes (stammen) or lineages (geslachten), each of which was valued higher than the next. The first and most distinguished was the "Tribus" of the Brahmins (Rogerius 1651, 2-3). Their office was to teach others and particularly to inculcate heathenism (ibid., 29-30). The law book of these heathens was the Veda, a text which contained everything they had to believe and all the ceremonies they had to perform. It ascribed a special status to the Brahmin tribe and provided them with certain privileges and prerogatives by divine injunction (ibid., 3, 26). The Jews also played a central role in Rogerius' account, both implicitly and explicitly. In the notes to the 1651 publication of his work, a commentator pointed out the many resemblances between Jewish institutions and practices and those of the Brahmins (occasionally, he also compared the customs of the Indian heathens to those of other peoples like the Arabs, Chaldeans, or Egyptians). In several 
cases, the notes even drew upon biblical references to suggest that the Brahmins had adopted practices and stories from the Jews (ibid., 10-11, 33, 60).

What is striking about these two accounts is the parallel they draw with the Old Testament Jews. At first sight, this may appear as a typical instance of describing the unknown in terms of the known. While true, such a claim misses what is happening in these texts: the very structure attributed to the "Gentile" people of India by these authors appears to transform it into a variant of the ancient nation of Israel. That is, the descriptive terms invoked by Della Valle and Rogerius indicate that they had already ordered their perception of the Indian people and traditions by mapping these onto the Jewish nation and religion described in the Bible.

The image of "a heathen nation" made up of "tribes" or "lineages" derived from the conception of the Jews as a nation consisting of tribes that were traced to different forefathers and united by a common religion and worship of God. When Della Valle said that "the employment" of the Brahmins is nothing but "the divine worship and the service of temples and learning" and that they hold "the office of priests," he had already transformed them into an equivalent of the tribe of the Levites, whose role in Jewish religion was described along similar lines (Grey 1892, 77-80). It is after having conceptualized "the heathen nation of India" as a variant of the ancient nation of Israel that these seventeenth-century authors then postulate explicit similarities between the Indian heathens and the Jews. The Brahmins among the Gentiles, Della Valle said, resemble the Levites among the Jews. In fact, the notes to Rogerius' work $(1651,10-11,33,60)$ added, it was not simply the case that Jews and Brahmins had many things in common, but also that the latter had adopted practices and stories from the former.

\section{Tribes and Priests}

According to the Old Testament, the tribes of the Jews had become one nation through a covenant with God. The offer and substance of this covenant was revealed to Moses at Mount Sinai and engraved in the tables of the Decalogue, which were then deposited in the ark of the covenant. While the laws given with the covenant expressed God's requirements of Israel, His offer of covenant also came with a divine promise: "You shall be to me a kingdom of priests and a holy nation" (Exodus 19:6). The priesthood had the responsibility of maintaining the unique covenantal relationship with God and possessed the prerogative to expound the Mosaic law, minister to the ark, and sacrifice at the central sanctuary (McCready 1979-1988, 965; Rehm 1992, 305).

Members of one of the tribes, that of Levi, were set apart and divinely appointed as priests to perform the religious ceremonies (or as lower priests that served at the temple). These Levites held the office of priesthood not because of a vocation, but because it was an exclusive hereditary office 
passed on from generation to generation. With this office came special privileges that distinguished them from ordinary Israelites:

A drastic and clearcut distinction was made between the sphere of the cult and the rest of the community. ... The 'realm of contact with God' (the sacrificial places) had limited access and demanded skilled entrance. Only one group of people was permitted, by the grace and appointment of God, to come into contact with the holy areas-the priests. (McCready 19791988, 967)

The Levite priests also played a central role in the assessment and treatment of impurity. Disease was considered the tangible embodiment of an impure spirit, which had to be cured through specific acts of purification. "The priests dealt with impurities and diseases as a regular part of their profession, for the continued presence of impurity would eventually undermine their sacrificial system and the status of their holiness as representatives of the people." Old Testament passages show that this "kind of activity eventually grew into a highly sophisticated system of judging and anticipating impurities of animals and carcasses, bodily disorders, etc., as well as impurity of corpses" (ibid., 968).

The basic concepts of this account of the Jewish nation, I would like to suggest, structured the experience of early modern European observers of Indian society. These authors understood the division of the Hindu people into "castes" along the lines of the tribes of Israel and their subdivisions into clans. The Brahmins were the equivalent of the Levites or "the tribe of the priesthood." Once this basic structure was in place, later authors began to draw on the same set of conceptual resources to make sense of the traditions and practices they encountered in India. On the one hand, these descriptions of caste explicitly compare the practices and religion of the Hindus (or Indian heathens) to those of the Jews. On the other hand, they implicitly model the people and culture of India onto the Jewish nation and religion by using the relevant concepts from the Old Testament as though these offer adequate terms to understand a people living more than 1,500 years later in a region far away from the Middle East.

In a work translated into English by the Deist John Toland and published in 1705, a French author of uncertain identity, named De la Crequinière, argued that the practices of the Indian pagans corresponded with those of the Jews. He admitted that many of his conclusions about the agreement between the customs of the Indians and those of the Jews and other ancient peoples were conjectures. But some he presented as basic facts: "The Pagan-Indians are divided into Tribes, as formerly the Jews were" and besides the general division, "each Tribe is divided into an infinite number of others, which are quite different from one another, either in their Food, or in something else." What the Jews called 
tribes, he added, the Indians "call Castes, i.e. Clans." Both knew of a hierarchy but this was much stricter among the pagan-Indian nation, where a strict antipathy ruled towards the most contemptible castes such as that of "the Parias" (La Crequinière 1705, 70).

Again, this parallel between the religion of India and that of the Jews should not be mistaken for a simple mapping of the unfamiliar onto the familiar, by opening up "the possibility of comparing the religion of the gentiles of India to more familiar religions, using the Jews as a point of passage" (Subrahmanyam 2010, 201). This kind of explanation ignores and trivializes something much more fundamental: the early modern Christian understanding of the ancient nation of Israel described in the Old Testament functioned as the framework for making sense of the people of India and provided terms of description that would remain central to future European accounts of India, its religion, and its social structure.

Without invoking any explicit analogy, authors deployed concepts that transformed the religion of the Hindus into a variant of that of the Jews. This becomes clear in the writings of the eighteenth-century East India Company servants. In a work published in 1763, for instance, Robert Orme (1763, 3-4) referred to the plethora of "casts or tribes" among the Indians and suggested that the Brahmins are "the tribe of the priesthood," whose doctrines are followed implicitly by the whole nation. His colleague Luke Scrafton $(1761,6-7)$ argued that the custom distinguishing the Indians from the rest of humankind is the division of the natives into tribes. He noted that "the four principal tribes," namely "the Bramins, Soldiers, Labourers, and Mechanics" are subdivided "into a multiplicity of inferior distinctions" and claimed that, among each of these tribes, Brahmins have the care of religion allotted to them (Scrafton 1761, 8-9). In what he claimed was an excerpt from "the scriptures of the Gentoos," John Zephaniah Holwell $(1765,345)$ wrote about "the holy Tribe of Bramins, who were chosen and appointed by Bramah himself, to preach the word of God, and labor the salvation of the delinquents." Again and again, the claim was that the Brahmin priesthood possessed the same type of privileges and prerogatives in religion that the Jewish priesthood had known. "The tribe of Brahmins," Thomas Maurice $(1800,25)$ noted, "is alone allowed to read the Vedas; and they explain them as they please to the other three tribes, who receive implicitly the interpretation of their priests."

At times, the reports about "the religion of the Hindus" continued to draw explicit comparisons and present these as salient facts, after already having conceptualized this "religion" as a variant of Judaism. In the introduction to his Code of Gentoo Laws (1776) - the first English translation

\footnotetext{
${ }^{1}$ These views on the conformity between the customs of the Jews and those of the Indians would soon spread widely across the educated classes of Europe. De la Crequinière's text was included as a section on Indian religion in the bestseller compilation Cérémonies et coutumes religieuses de tous les peuples du monde (1723-43), which was translated, pirated, and imitated across Western Europe (Hunt, Jacob and Mijnhardt 2010).
} 
of a dharmashastra compilation and an important text of this period - Nathaniel Halhed pointed out the similitude between "the Mosaical and the Hindoo dispensation" and had the following to say about the Brahmins:

Indeed the whole Office, as well as the sacred Preeminence of the Braminical Tribe, is almost an exact Counterpart of that of the Levitical: The Levites were particularly forbidden Wine; so are the Bramins. The Levites were more than others enjoined to avoid the Contact of all Uncleanness; so are the Bramins. The Levites were to assist the Magistrate's Judgment in difficult Cases; so are the Bramins. (Halhed 1776, lxxiii)

Similarly, writing in late eighteenth-century Bengal, the Baptist missionary William Carey made the following claims in a passage about "the character of the Hindoos":

One cannot help remarking the similarity there is between many of the practices of the Hindoos and the institutions of the Levitical law. Their ideas of contracting uncleanness by touching a bone, a grave, a dead person, or any unclean animal, are uniformly very much like the precepts of the law respecting these things: for after touching any such thing, they always bathe and change their clothes. The cast also bears some resemblance to the Jewish law, which required the tribes to be kept separate, and not to intermarry, lest they should mar their inheritance. ... The distinction of the Levites from the rest of the people for holy purposes, and the different orders of the Levites, have an affinity to the proper employment of the Brammhans, and to the different classes of that tribe, much more striking than you would imagine. The Brammhans are a tribe entirely separate to the maintenance of learning, and the performance of religious rites: but they are of many different orders, who are all of them attached to the different tribes of Hindoos, and are ranked accordingly in the society of the Brammhans. (Cited in Staughton 1811, 180-81)

The role of the Brahmins in the religion of India was quasi identical to that of the Jewish priesthood then. They had the duty to perform its ceremonies of divine worship and the prerogative to expound the laws of religion. They received privileges such as the special access to the sacred that set them apart from ordinary believers. The Brahmins also shared the concern for purity with the Levites and, like them, had developed a sophisticated system of judging, anticipating, and remedying impurities. Consequently, their many "ablutions" constituted another striking fact related to the Hindu religion, since these practices corresponded to the purification ceremonies of the Levite priests. In the Bible, 
these practices were founded in the Jewish law revealed by God to Moses; in India, these authors pointed out, "the cast" appeared to play a similar role.

\section{Lawgivers and Outcasts}

The figure of Moses was another crucial component of the biblical account of the nation of Israel. He was the deliverer of the Jews from captivity and the prophet to whom God revealed the laws of the covenant at Mount Sinai. In his work The Hebrew Republic (2010), Eric Nelson shows that the Old Testament and the Mosaic law played a major role in the political thinking of the seventeenth-century Protestant world. In the wake of the Reformation, European thinkers increasingly came to see the Hebrew Bible "as a set of political laws that God himself had given to the Israelites as their civil sovereign. Moses was now to be understood as a lawgiver, as the founder of a politeia in the Greek sense." During this era, the text began to function as the source for understanding the perfect political constitution designed by God (Nelson 2010, 16). The covenant law came to be seen as the foundation or constitution of a new nation headed by God (Elwell and Beitzel 1988, 533-4).

From the late seventeenth century, this conception of Moses as a lawgiver fed into a general theory which claimed that every civilized nation had its origin in a first legislator who provided it with a legal foundation. In the act of constituting such nations, ancient lawgivers drew upon the sense of divinity implanted in every man to pretend that they had received a divine revelation as to the laws that a people should follow in order to obey God (or the gods). Thus, these lawgivers were (false) variants of Moses: ingenious impostors who had used religion to secure strict obedience to a set of laws that were in fact the civil laws of a nation. The success in establishing a nation depended on this merging of civil law with divine injunction (Blount n.d., 3; Bolingbroke 1777, 58; Herbert of Cherbury 1768, 39-40, 92-3; Jacolliot 1880, 224-5; Wilkins 1678, 44).

It is not yet clear to me why such importance was given to the fact that the lawgivers had presented the civil laws of a nation as religious obligations. However, the eighteenth-century European descriptions of India do show how significant this cluster of ideas had become in the attempt to understand alien cultures. Scrafton speculated that the hierarchical division of people was the invention of an ancient legislator ("Brumma") who left "the Gentoos of India" with a sacred book (the "Vidam") that instituted their religion and introduced rules of pollution and purity. The Hindus consider their customs as part of their religion, he asserted, because these are sanctioned by the divine character of their legislator (Scrafton 1761, 8-9). A French nobleman who travelled to India in the same period noted that the civil laws of the Hindus were all maxims of religion, which accounted for the fact that civil law had a stronger hold here than among any other people on earth. The first legislators of the Hindu nation, the ancestors of the Brahmins, had thus firmly instituted the caste 
order by making it indivisible from religion (Deloche 1971, 372-3). Or as an entry in the Asiatic Annual Register for 1799 put it:

The laws of the Hindûs are intimately blended with their religion. They believe them to have been promulged by Menu, the son of Brahma, and to have received the sanction of God. The strict observance of them is therefore enjoined as a religious duty, and the smallest breach of them is deemed a glaring impiety. No human power is authorised to alter, much less to annul them. (Anonymous 1800, 5-6.)

Many authors agreed: behind the religion and civilization of the Hindus must have stood an ancient lawgiver who had presented the laws of this nation as divine revelation (Bernier 1671, 125; Holwell 1765, 7, 22; Jones 1796, iii-iv; Lord 1630, 40-41; Martin 1769, 462). This first legislator - initially identified as Brahma and later as Manu - was supposed to have performed a role very similar to that played by Moses as the covenant mediator and lawgiver of the Hebrew nation. By invoking a divine revelation, he had made the customs of the Hindus part of religion and given them a foundation in sacred law; thus, he had founded the Hindu nation.

Once this isomorphism was in place, other aspects of Judaism could help the Europeans to structure their understanding of the foreign culture of India. Again, De la Crequinière $(1705,76)$ stated explicitly what remained implicit in other descriptions: "The Indians have among them such Persons as are Excommunicate, as formerly the Jews had. He that is Excommunicate is said to lose his Caste, i.e. he is no more to be reckon'd as one of the Members of his Tribe." This was a reference to the punishment of herem or "excommunication" in Judaism, which entailed "the expulsion of a Jew from all aspects of Jewish community life" (Karesh and Hurvitz 2006, 205). By violating the Mosaic law, one could put oneself outside the covenant relationship and, for this reason, be excommunicated (Silva and Tenney 2009, 458). This involved a practical prohibition of all intercourse with society. The meaning of the Hebrew terms used to refer to this practice indicate its impact: "to be excluded or cut off," "banish," “desolation" or "thing of horror" (Ridge 2003, 521). The Talmud not only specified twenty-four offences that could lead to herem but also stipulated the distance that members of the Jewish community should keep away from the excommunicates.

Now, as we notice in De la Crequinière's words, the Christian understanding of the Jewish practice of herem seems to have played a significant role in the crystallization of another idea that would prove central to the European image of Indian society: the idea that there was a separate class of people among the Hindus, which existed outside of the caste hierarchy and its laws. Already in the mid seventeenth century, Rogerius $(1651,10-11)$ discussed "the Perreaes" as a separate lineage 
considered too unworthy by the heathens to belong to their tribes; they existed outside of the four principal tribes of the heathen nation and lived in separate parts of towns and villages. This group was considered impure by the Brahmins and could therefore not use the same water wells or access the temples - sacred places defiled by their presence. In the notes (or para-text), the commentator again related this to the concerns about purity among the Jews and referred the reader to biblical verses from Leviticus and Numbers.

During the eighteenth century, European authors took further steps in what appears to have been a mapping of the idea of a fifth class of "outcasts" onto the institution of excommunication among the Jews. Scrafton, for instance, pointed to a group called "the Hallachores, who I cannot call a tribe, being rather the refuse of all the tribes." These had been excluded from the system established by the ancient legislator because they had violated its laws:

All the different tribes are kept distinct from each other, by insurmountable barriers; they are forbid to intermarry, to cohabit, to eat with each other, or even to drink out of the same vessel with one of another tribe; and every deviation in these points, subjects them to be reject by their tribe, renders them for ever polluted, and they are thenceforward obliged to herd with the Hallachores. (Scrafton 1761, 8-9)

One of his colleagues in the East India Company similarly noted a fifth group distinct from the four main castes, called "the Chandalas," which consisted of those expelled from all castes. This expulsion was "a punishment inflicted for certain offences." These people, he wrote, were denied any rank in society, could not enter a temple and be present at any religious ceremony or serve in any public employment. "Hence the punishment of expulsion, which is supposed in its consequences to extend even to another life, becomes more terrible than that of death" (Craufurd 1790, 124).

These were the first of hundreds of similar descriptions of "the outcasts," "the casteless" or "the untouchables" that would be produced in the coming centuries. Nineteenth-century authors continued to describe exclusion from caste in the same way. As before, this took the form of the conviction that there is a separate class of impure people placed outside of the caste system and subject to the greatest abhorrence and vile treatment. There are indications that this continued to build on describing expulsion from caste as the structural equivalent of excommunication among the Jews. In a famous text that functioned as a handbook for the training of East India Company officials for many years, the Abbé Dubois $(1817,29)$ described the practice as follows: 
Expulsion from caste, which is the penalty of those who are guilty of infringing the accustomed rules, or of any other offence which would bring disgrace upon the tribe if it remained unavenged, is in truth an insupportable punishment. It is a kind of civil excommunication, which debars the unhappy object of it from all intercourse whatever with his fellow creatures. He is a man, as it were, dead to the world. He is no longer in the society of men. By losing his caste, the Hindoo is bereft of friends and relations, and often of wife and children, who will rather forsake him than share in his miserable lot. No one dares to eat with him, or even to pour him out a drop of water. If he has marriageable daughters, they are shunned. No other women can be approached by his sons. Wherever he appears, he is scorned and pointed at as an outcast. If he sink under the grievous curse, his body is suffered to rot upon the place where he dies.

Those who transgress the rules of the institution of caste in India, another missionary wrote, become "the victims of civil and social disabilities, as if already dead" (Roberts 1847, vi). The argument here is not that no such practices of ostracizing people existed in India. Rather, I suggest that the way in which European authors structured their descriptions drew upon a conceptual apparatus that represented these practices as variants of Jewish herem. More evidence is needed to substantiate this suggestion, but even the terms of "horror" and "social death" used in such analyses appear to go back to the vocabulary used to characterize this practice among the Jews.

\section{The Factual Structure}

The point of this section is not simply that early modern Europe relied on the Bible and its conceptual resources to come to systematic descriptions of Indian culture and society. Others have shown that European scholars drew upon the chronology and ethnology of the Old Testament as a framework for making sense of the diversity of peoples encountered in the human past and foreign parts of the world (Sutcliffe 2003, 58-78; Trautmann 1997). The tentative hypothesis offered here is stronger: the basic factual structure that is still attributed to "the caste system" is dependent on understanding the Hindu people and culture of India as a variant of the nation and religion of the Jews, as it was described in the Old Testament and understood by post-Reformation Christendom. Without this background, Europeans could not have characterized the many groups and traditions they encountered in India as one nation consisting of a hierarchy of tribes or castes, founded by a lawgiver, and dominated by the tribe of the priesthood and its privileges and prerogatives.

Today's textbook discourse about the caste system still presents the Hindus as a people divided into a hierarchy of castes and the Brahmins as the privileged priestly caste. It continues to say that certain groups in Indian society are the descendants of people originally expelled from their caste 
as a punishment for violating the laws of the caste system (see Klostermaier 2007, 296-7). In eighteenth-century descriptions, we could still see what would become murky in later writings: such descriptions order a set of phenomena observed in Indian society by describing them as equivalents of practices and institutions in Judaism. The tribe of the priesthood were the privileged expounders of the Mosaic law. Excommunication was a punishment for the violation of this law, which excluded one from the covenantal relationship with God that constituted the Jewish nation. Mutatis mutandis, the Brahmins formed the caste of the priesthood and certain groups in India were "outcasts" permanently excluded from the caste hierarchy - the Hindu lawgiver's system that had constituted the nation in the name of divine revelation - because they had at one point violated its laws.

\section{The Morals of a Heathen Nation}

So far we have ignored the crystallization of the moral dimension in the European discourse about caste. There is a reason for this. When early modern European authors gave factual descriptions of "caste" and "religion" in Indian society, they often expressed negative judgements about "heathen idolatry." They also condemned some of the customs and practices they discovered in this part of the world. However, it took them much longer to conceptualize the distinct moral structure that would be attributed to the caste system: a social organization that deceives people into following a set of immoral injunctions as moral obligations.

Seventeenth-century travellers discerned many of the practices that later authors would consider as loathsome manifestations of the scheme of caste. Della Valle, for instance, noted that several groups in Indian society avoid touching each other and eating together. They conceive themselves to be polluted by communication with less noble groups and purify themselves "from the defilement by washings and other arrogant Ceremonies." Significantly, he gave a factual account of these practices without discussing their moral status: he found it "a pretty sight to behold the great respect which upon this account the ignoble bear to the more noble then themselves, and how upon meeting in the street the ignoble not onely [sic] give place, but dance wildly up and down for fear of rushing against the noble, and polluting them in any measure" (Grey 1892, 80-81). The reference to "arrogant Ceremonies" is the only statement of disapproval in this passage. Again this derived from the description of Indian religion as a variant of Judaism: a religion of external ceremonies wrongly believed to be pleasing to God.

That this statement did not involve a general moral disapproval of caste-related practices is clear from Della Valle's account of "a strange Custom," which he said sprang from the different tribes' averseness to communicate with each other and which he was "delighted not only to see, but also sometimes out of gallantry to imitate in conversation." This custom, which he baptized "drinking in the Air," is that of drinking from a vessel without touching it with the lips (ibid., 81-2). This educated 
Italian observed the very same practices that would later inspire the strongest moral condemnations of the caste system but took a morally neutral stance towards them (ibid., 83-4). Similarly, the Calvinist cleric Rogerius gave neutral accounts of the relevant practices of the Brahmins and of the division of the heathen nation of India into four tribes and a separate class of impure people.

\section{The Power of the Priesthood}

Naturally, moral judgements were not absent from the European accounts of Indian society during the seventeenth and eighteenth century. From a Christian perspective, a society corrupted by false religion and devil worship could not but harbour many immoral practices. Once the Brahmins had been identified as the priests of the local brand of heathen religion, they became the object of many a moral diatribe. From the seventeenth century, European authors of all stripes and colours began to accuse the Brahmanical priesthood of establishing the hierarchy of castes in its own interest.

In De La Crequinière's text, we note how closely related this was to his understanding of the Indian religion as a duplicate of that of the Jews. He left no doubt that both nations shared the miserable condition of enslavement to a tyranny of priests and laws:

First, Both of them liv'd in hard Bondage, to which they were so much the more subject, because they lov'd it, and even ador'd their Captivity; I mean that of the Law, which was the hardest Slavery. ...[T]hey are only Machines, which are mov'd by their Priests; who inspire them either with Boldness or Fear, according as they assure them of gaining or losing a Battel. They Fight sometimes in Defence of their Religion with great Obstinacy, which being founded upon some Promise of their Diviners, cannot proceed but from a Furious Rage: And these Miserable Wretches do not perceive, that they do but strengthen their Fetters, and increase the weight of their Chains, while they give the Priests occasion, by their Victories, to confirm the Law, or rather their own Tyranny. (La Crequinière 1705, 136-7)

Robert Orme wrote that the "influence of priestcraft over superstition is no where so visible as in India" and noted that the Brahmins derived many temporal advantages from their spiritual authority (Orme 1753, 432 and 1763, 3-4). Another East India Company servant, Georg Forster, wrote the following about the "Shastre," a text he identified as a commentary on the Vedas:

From the Shastre proceed those preposterous and irreconcileably [sic] superstitious ceremonies which have been dragged by their doctors into the Hindoo system of worship; all of them tending to shackle the vulgar mind, and produce in it a slavish reverence for the tribe of Bramins. The privilege of reading the Baids and expounding its texts is only allowed to 
them, and prohibited under severe penalties from the inspection of the other casts. By the sole investment of this singular authority, the priest is left at liberty to explain the original doctrine as may be the most conducive in consolidating the power and promoting the interests of his order. (Forster 1785, 23-4)

In such observations, we witness the emergence of a dimension that would be central to the future conception of the caste system: under the guise of religion, the Brahmin priesthood had represented certain ceremonies as religious duties and thus enslaved the Hindu believers to a tyranny of law.

This account was built around two interrelated clusters of ideas from the intra-Christian debates that had taken place in Europe during the preceding centuries. The first is the critique of Judaism as a religion of bondage to law and ceremony. This originated in the view that Christianity and its new covenant of freedom and grace had superseded the old covenant of law that formed the core of Judaism. Certain passages in the New Testament indicated that the coming of Christ had abrogated the Mosaic law or at least many of its elements. The Gospel, Christian theologians argued, had made all kinds of restrictions and rules of the nation of Israel's covenant with God superfluous to religion. Such customs and ceremonies were now indifferent to the worship of God, for His revelation in Jesus Christ had brought all nations and races together into one people - irrespective of language, custom, and external ceremonial. However, this account continued, the stubborn Jews continued to take the Law literally and practice empty ceremonies; they could not see that Christianity had supplanted Judaism, that "the New Testament" made void "the Old Testament" (Falk 1992, 1-100; Hubbard 1996, 961). Since the power and privileges of the Jewish priesthood depended on the belief in the old covenant, it kept in place the bondage of law.

Secondly, these accounts of the Brahmin priesthood also derived from the Protestant Reformation's attack against the Roman-Catholic Church. What had started out as a rejection of the authority of the papacy and its clerical hierarchy would soon give rise to a more general critique of "the religion of the priest." This went hand in hand with the above ideas about Judaism: one of the popular tropes among Protestant authors was to liken the "popery" of the Church to the rules and rites of rabbinic Judaism (Sutcliffe 2003, 85-6). In fact, these characterizations transformed both Catholicism and Judaism into negations of the ideals of Protestant Christianity: the latter stood for Christian liberty and inner spiritual faith; the former embodied clerical tyranny and servitude to external ceremonial and laws. This contrast then served as a general template for conceptualizing "false religion" or, in secular sounding terms, "organized religion": it was a tyranny of laws and ceremonies imposed by a priesthood that used the name of God to claim religious authority (see Balagangadhara 1994; De Roover 2015, 169-233; Gelders and Derde 2003; Gelders 2009). 
By the eighteenth century, these two clusters of ideas appear to have become so generic and widespread that they could constitute the conceptual background for the common European accounts of Indian culture. The description of the Brahmins as a priesthood with absolute dominion over the minds of the Hindu nation would soon spread widely across Western Europe. It appeared in popular texts like the gazetteers, geographical dictionaries and encyclopaedias of this age and gradually ensconced itself in the educated public's image of India. ${ }^{2}$

\section{Moral Ambiguity}

Nevertheless, the account of caste as an immoral social system had not yet crystallized into a stable picture in this era. For Scrafton (1761, 8-9), the injustice of the excommunication of certain people from social life was an introduction into the system of the Hindu lawgiver rather than a core characteristic. A reviewer of a book that accused the Brahminical system and its division of castes of being "more injurious to morality than any other ever invented by the craft of designing men" argued that this thesis was completely falsified by the centuries-long flourishing of the Hindu people and by its awareness of the beauties of moral sentiment. He added: "As to the epithets of 'crafty Brahman, cunning Brahman, mean Brahman, cheating Brahman, Ec. Ec.' which our author so profusely bestows, they are suitable enough to the idle prating of a youth on his first arrival in India, but are unworthy of a grave doctor, who aims at a place amongst the investigators of Asiatic history and science" (Anonymous 1803, 29).

Some of the most influential texts of this period showed ambiguous attitudes towards the moral status of caste in India. For instance, in his translation of the text he called the "Code of Gentoo Law," Halhed (1776, xlvviii-xlix) commented on the preliminary discourse which he said had been written by the Brahmins: "Nothing can be more remote from a superstitious Adherence to their own domestic Prejudices, or more truly elevated above the mean and selfish Principles of Priestcraft, than the genuine Dignity of Sentiment that breathes through this little Performance." Surprisingly, this was the very preface where the hierarchy of the four varnas was explained. "These four great Tribes," Halhed (1776, xlix) continued, "comprehend the first grand Divisions of a well-regulated State." Things were no different in the case of the famous Orientalist William Jones and his translation of Manu's "code of law." While he disparaged this code as "a system of despotism and priestcraft, both indeed limited by law, but artfully conspiring to give mutual support, though with mutual checks,"

${ }^{2}$ In the Dutch Republic, France, and Britain, this is seen in popular texts like Bernard and Picart's Religious Ceremonies of the World (Hunt, Jacob and Mijnhardt 2010). In Britain, we find this image in the entry "Hindoostan, or India" in a series of popular Gazetteers or Geographical Dictionaries of this age, which largely reproduced Scrafton's account and which saw dozens of editions and imitations in the following decades. See the entry "Hindoostan, or India," in the seventeenth edition of Brookes's General Gazetteer (1820); see the similar or quasi-identical entries in Guthrie 1782, 546; Landmann 1835; Marshall 1840, 377; Walker 1798). 
he also wrote that it possessed "a spirit of sublime devotion, benevolence, and tenderness to all sentient creatures" (Forbes 1805, 28-9). In other words, the claims about the supremacy of the Brahmin priesthood could still go together with ambiguous moral assessments of other dimensions of caste.

This ambiguity was not limited to Orientalists but extended to the practices and reflections of Christian missionaries. Many viewed the social distinctions of caste as a phenomenon in Indian society that led to unfortunate forms of discrimination. They admitted that such behaviour would need remedying in time and had no doubts about the fact that the sacerdotal tyranny of the Brahmins deserved destruction. However, these missionaries did not regard caste distinctions and practices as parts of an immoral and idolatrous system irreconcilable with Christianity. In fact, they accommodated many such practices in the local Christian communities and churches. Thus, the earliest Lutheran missionary to India, Bartholomeus Ziegenbalg of the Tranquebar Mission in present-day Tamil Nadu, allowed converts from different castes to sit in separate divisions in the church and even to separately go for communion at the Lord's table. Similarly, the most successful Protestant missionary of eighteenth-century India, Christian Friedrich Schwarz, tolerated caste distinctions and never denounced them as unacceptable (see Kaye 1859, 350-57).

As John Kaye recounts in his historical narrative of Christianity in India, this stance survived well into the nineteenth century. Consider, for instance, the weighty questions raised by a prominent church official, Reginald Heber, the second Bishop of the Anglican Diocese of Calcutta:

Is there no such thing, he asked himself, as Caste in Europe? Is there no such thing as Caste in America? Do not the high and the low sit apart in our English churches? Do not our welldressed high-caste folks go up first to the altar to communicate? Do high and low sit down to meat together-do their children attend the same schools? Are there no pariahs amongst us? In other civilized countries, is there not a prevailing sense of Caste, apart from all associations of worldly distinction? (Kaye 1859, 355)

Certainly, the Bishop argued, it is a Christian principle that all men are equal in the sight of God, but it is equally certain they are not equal in the sight of Man. Social distinctions exist in all societies, he added, and it is a fair presumption to say that God never intended all men to be equal. Hence, caste should be tolerated as a type of social distinction similar to those that exist elsewhere (ibid.).

Generally, the eighteenth-century accounts present us with many elements of the discourse about the caste system that would become dominant in later centuries. They suggest that the Hindu religion represents the civil laws of the Hindus as products of divine revelation. Feigning such a 
revelation, the ancient Hindu legislator wrote these rules into his sacred code of law. As the tribe of the priesthood, the Brahmins enforce this system and expound its sacred scriptures and laws, which grant them many privileges and set them apart from other Hindus. Now, if so many recognizable elements of the dominant discourse about the caste system were already present, the question "what was missing?" becomes all the more pertinent. That is, which other elements were still needed that would allow for the emergence of the dominant picture of caste as an immoral social system - an institution that perversely renders immorality into a duty?

\section{The Evil of Caste}

In the first decades of the nineteenth century, a series of works appeared that left no doubt as to the immorality of the caste system. In his observations on the state of Indian society delivered to the British Parliament, the East India Company chairman Charles Grant pointed out the following: "Despotism is not only the principle of the government of Hindostan, but an original, fundamental, and irreversible principle in the very frame of society" (Grant 1813, 44; emphasis added). How so? Well, the Hindu law rests entirely on the fundamental position "that certain classes or races of the society are in their elementary principles, in the matter from which they were formed, absolutely of a higher nature, of a superior order in the scale of being, to certain other classes."

Now the evils that flow from such an arrangement, are infinite. Other modes of despotism lead in their very excess and abuse to a remedy, but here the chain of servitude is indissoluble and eternal. Though the highest orders be guilty of the most flagitious wickedness, pervert the use of power, become weak, arrogant and oppressive, the frame of society can suffer no change; that order must still continue in the enjoyment and exercise of all its vast privileges and prerogatives. The lowest rank, on the contrary, is doomed to perpetual abasement and unlimited subjection. It has no relief against the most oppressive and insulting tyranny, no hope of ever escaping from its sufferings. (ibid.; emphasis added)

Under the fatal influence of this abominable system, William Ward agreed, the members of all four varnas have become inept and miserable. The Hindu system of caste, he added, is wholly the work of the Brahmins, who enslaved all other groups. "The rules of the shastras respecting the shoodrus are so unjust and inhuman, that every benevolent person must feel the greatest indignation at the Hindoo lawgivers, and rejoice that Providence has placed so great a portion of this people under the equitable laws of the British Government" (Ward 1822, 91-2; emphasis added). This system also had horrible consequences: "But not only is the cast contrary to every principle of justice and policy; it is repugnant to every feeling of benevolence ... In short, the cast murders all the social and benevolent 
feelings; and shuts up the heart of man against man in a manner unknown even amongst the most savage tribes" (ibid., 145-6).

There is no need to multiply similar quotations to note that a shift occurred in these writings. It was considered self-evident by these authors that immoral principles are inbuilt into the very frame of Hindu society. "The cast" or the system of caste now counted as an oppressive tyranny opposed to every principle of justice, whose rules compel people to be unjust and inhuman to such an extent that all social and benevolent feelings are killed. In other words, in the eyes of these authors, caste had become an immoral social system (for more illustrations, see Anonymous 1818).

\section{Religious or Not?}

Is this shift all that remarkable? Some would situate it in a larger conflict between two groups of British colonials in this era: the Orientalists, relatively sympathetic to Indian culture, and the Anglicists, who argued for its substitution by European education and rational religion (Zastoupil and Moir 1999). Grant was a staunch evangelical and Ward a Baptist missionary; both shared the agenda of convincing the government of the need for allowing the propagation of the Gospel in British India. With this aim in mind, they stressed how terrible the state of society was and how false religion dominated every sphere of life among the Hindus. The evil of caste needed to be destroyed, not only by means of benign rule but also through the dissemination of true religion. In contrast, many other scholars and officials in the same period gave sympathetic accounts of Hindu society and argued against disrupting its religion and customs through missionary activity (for instance, see Stuart 1808).

While there is truth to these claims, they lose sight of a crucial point: it is the conception of the caste system held by these Protestants - and not that of the Orientalists - that survives today in its basic outlines. That is, it is the missionaries who propagated the account of the caste system as an immoral social structure at the core of Hindu religion. It is they who insisted that this system compelled the Hindus to act by the most unjust and inhuman principles. And it is this step that appears to have constituted the discourse about the immorality of Indian society. Therefore, it is all the more important to find out which new element(s) had caused this shift in the European understanding of caste. Had the missionaries discovered new facts about the structure of Indian society, which revised the views of the earlier Orientalists and other scholars? Had systematic study really laid bare the immoral core of the caste system? Or was this change rooted in a reconfiguration of their own religious views?

To find answers to these questions, we need to turn to a dispute that had emerged among Christian missionaries in seventeenth-century India. The "Malabar rites controversy," as it was later called, concerned a simple question: Did usages like the privilege of certain castes to wear a cotton 
thread around the torso, carrying a tuft of hair on a shaven head, or applying sandalwood paste to one's face count as manifestations of religion or merely as civil observances? This dispute had its origins in the work of the Jesuit missionary Roberto De Nobili, who lived on the Malabar coast during the seventeenth century. He had not only adopted the dress and demeanour of an Indian sannyasin but also allowed his converts to keep their "national customs, in as far as these contained nothing wrong and referred to merely political or civil usages" (Brucker 1910, 558-62). That is, he did not compel Christian converts to renounce practices such as wearing the markers proper to one's caste. He refrained from doing so because he viewed these as parts of a civil institution that divided the Indian nation into "four grades of civil functions to which there corresponds a similar gradation in nobility" (De Nobili 2000, 57-62).

Like Della Valle and Rogerius, De Nobili saw the Indians as a nation consisting of distinct clans or tribes ranked according to civic function and nobility. He identified the "Laws of Manu" as the authoritative civil law book that sanctioned this social organization of the Indian nation. However, he denied that the Brahmins constituted a priesthood. They were wise men with knowledge of the different sciences, he said, who received exceptional respect not because of some special religious status but because of their learning. Consequently, the ranking of citizens and the privileges of certain groups in Indian society derived from civil status rather than religion (ibid., 63-76).

De Nobili's position on caste-related customs would soon be challenged by other missionaries and this led to tension between him and some officials of the Jesuit Society and the Church in Rome. However, when he put forward arguments and produced evidence, the Jesuit officials were satisfied and the Holy See provisionally decided the question in his favour. In an Apostolic Letter, Pope Gregory XV permitted Indian Christians to continue several of the relevant practices like wearing the sacred thread and performing ritual baths. Again, the decisive factor in these judgements about the customs of caste was the verdict that these were not inextricable parts of the religion of the Indians (Brucker 1910).

Why was this so crucial? The concern about the religious nature of social practices went back all the way to early Christianity. After this religion had become dominant in the Roman Empire, the reach of "pagan idolatry" in everyday life became a crucial question. The worship of false gods was not limited to the cults, the church fathers said, but had tentacles across social life. Any practice could now be examined in terms of its connection to idolatry, from carving statues to attending games. If Christian authorities decided that the practice in question was religious, it became a sinful violation of God's will and one of the devices invented to deceive people into worshipping the false god. In other words, whenever a practice could be connected to false religion in some way or the 
other, it entered the sphere of the prohibited; converts now had to renounce it (Balagangadhara 2014; Markus 1990, 16, 226).

Early Christianity had thus carved up social life into three spheres: all actions essential to the worship of God were obligatory; all those related to idolatry or the worship of false gods were forbidden; and everything that remained was permitted, since it was indifferent to religion and the worship of God. In the early modern period, the same standard began to determine the Europeans' moral judgements about the practices they encountered among pagan people in exotic parts of the world. If a practice was linked to false religion and idolatry, it could not but be immoral and forbidden; if it was merely civil or indifferent to religion, it was neutral and permitted. In India, this would prove decisive in the theological dispute about caste practices, which resurfaced again and again from the seventeenth century onwards.

In the early nineteenth century, the same dispute erupted in the south of India. After being consulted by local missionaries, Bishop Heber became involved in the issue of the religious and moral status of caste. On a journey through the south in the 1820s, he noted that several local missionaries had allowed their converts to preserve "very many of their ancient usages, particularly with regard to caste." "The old school of Missionaries," he added, "tolerated all this as a merely civil question of pedigree and worldly distinction, and in the hope that, as their converts became more enlightened, such distinctions would die away." In one case, high-caste Indians had made the unacceptable demand to have a separate cup for the Sacrament. Younger German and English missionaries, however, preached against caste and prevented its practices as much as possible in the arrangement of their schools and congregations. They had gone even further and interfered with ancient practices in marriage ceremonies and domestic festivities, because they denounced all kinds of practices as Satan's devices. One of the missionaries had "gone so far as, by way of punishment to compel a schoolboy of high caste to drink water from the cup of a Pariah" (Heber 1828, 444-5).

That both parties were at fault was clear to Heber. Still, he considered this question about caste as a major challenge facing the church in India:

The difficulty will be to ascertain how far the feeling of caste is really civil, and not religious, and how far the other practices objected to are really immoral or idolatrous. On these topics I am now busily making inquiry, and hope, in the course of my journey, to come at the truth so nearly as to prevent, at least, any gross scandal, without intrenching [sic] materially on what I conceive the natural liberty of the new convert, to live in all indifferent things in the manner which he himself prefers, and which his ancestors have preferred before him. (ibid., 445-6) 
Bishop Heber drew up a series of questions and submitted them to an Indian convert of exceptional intelligence and piety, known as Christian David. In response, David declared that caste was "purely a worldly idea," among the natives of Southern India, "not connected in their minds with any notion of true or false religion." Native converts from the higher castes, he said, avoided contact with low-caste proselytes, not on religious grounds but simply for social reasons. David related this stance to the coarse and indecent language and the less decorous and self-respectful way of life common among low-caste people, which were revolting to high-caste people. He profoundly regretted that young missionaries had begun to argue for the total repudiation of caste and had denounced the older generation of missionaries as "corrupters of the Gospel" for tolerating caste-related customs. After being informed by other European missionaries and Indian converts, Heber eventually concluded that caste - at least as it existed among converts - was an institution of social distinction differing little from the social exclusiveness that existed in Christian societies (Kaye 1859, 352-4).

Even among the missionaries and church officials who took such conciliatory attitudes towards caste, the ambiguity about its religious and moral status remained present: Were caste distinctions acceptable only among Christian converts, because they lost their religious significance once the natives left the Hindu fold? Was caste a purely social institution even among the Hindus, very similar to the social distinctions in Europe and America? Or did it instead have religious foundations in Hinduism?

This ambiguity soon gave way to a different stance and story. By the 1850 s, so Duncan Forrester shows in his Caste and Christianity (1980), a new consensus had crystallized among the Protestant missionaries in India. It was not simply the case that some specific set of customs was religious, they argued, but that the entire system of caste was a "sacred institution" to the Hindus and an integral part of "the whole system of idolatry." Converts now had to renounce all customs of caste as an expression of their embracing of Christ, for it did not concern a mere civil distinction but an institution to which the Hindus attributed a divine origin. Missionaries began to consider caste as the main obstacle to conversion: the system which held the Hindu religion together and protected it from disintegration in the face of the Gospel (Forrester 1980, 23-48). In other words, this Protestant consensus transformed caste into a religious institution. Thus, it was transferred from the sphere of things indifferent to that of false religion, the realm of the prohibited.

\section{Civil Law and Divine Revelation}

Let us now formulate a second tentative hypothesis: caste emerged as an immoral social structure in the European understanding of India, because it came to be seen as a religious institution built around a system of laws that provided the core structure of Hinduism and the foundation of the Hindu nation. This shift allowed for the 
birth of the conceptual entity that we call "the caste system" by bringing together several clusters of ideas into one integral whole: the claims about the nation of the Hindus as a variant of that of the Jews; the conception of the Brahmin priesthood and its practices as an instance of false religion similar to the institutions of Catholicism and Judaism; the idea that such institutions deceived the believers into following a set of human fabrications as though these were divine commandments; the claim that the Hindu religion revolved around external ceremonies and concerns about purity and pollution. By integrating these elements into a coherent entity called "the caste system," this shift provided order and stability to the European understanding of Indian culture and society.

The early nineteenth-century sources show that elements of the earlier descriptions of caste now coalesced into a picture of one single system of which the law and religion of the Hindus were held to be mutually dependent parts. Charles Grant explained this system to the British politicians and administrators:

The Hindoo law stands upon the same authority as the Hindoo religion; both are parts of one system, which they believe to have been divinely revealed. That law is regarded by them therefore with a superstitious veneration, which institutions avowedly of human origin do not produce; so that even under a foreign yoke, which in various particulars superseded its injunctions, it still maintained its credit. ... Nothing is more plain, than that this whole fabric is the work of a crafty and imperious priesthood, who feigned a divine revelation and appointment, to invest their own order, in perpetuity, with the most absolute empire over the civil state of the Hindoos, as well as over their minds. (Grant 1813, 43-5; emphasis added)

This passage brings together several elements. The charge that the Hindu priesthood feigned a divine revelation and appointment reflects the earlier notion that the Brahmins are like the Levites, the tribe of priests divinely appointed by God's revelation of the covenant. This comes together with the conception of false religion as the fabrication of clerics who usurped religious authority in order to pursue worldly interest. As crafty priests, the Brahmins invented "the whole fabric of caste" to invest in their own order absolute power over all believers. The Hindus mistook this system for a religious institution of divine origin because of the ploy that both its religious beliefs and its civil laws are divinely revealed. While the ancient legislator does not appear in this particular passage, Grant $(1813,56)$ made it clear elsewhere that Hindu customs (like "widow-burning") are presented as injunctions from a lawgiver believed to be divine and are therefore "admitted to have the force of a religious obligation." It is this fabrication of divine origin that enables the priesthood to dominate the civil state of the Hindus and not just their religious life, by deceitfully imposing civil laws as though these constitute 
religious obligations. Because of the superstitious veneration that follows from this, the system of caste and its injunctions could survive foreign rule in India, even when the rulers rejected some of these injunctions.

In brief, this shift brought these elements together to form a coherent conception of "the scheme of caste": a system that had merged civil law and religion into one whole by claiming a divine origin for itself. Protestant missionaries from a variety of denominations now began to argue that the inveterate distinction of caste is incorporated with the "whole religious economy" of the Hindus (Harvard 1823, 183), that the institution of caste is not "a mere political expedient" but "belongs to the religion of Hindostan" (Adam 1824, 27), that "caste is not a civil but a sacred institution,- - not an ordinance of human but of divine appointment" (Duff 1840, 123-4), that "Caste is not merely a political or social distinction, as many have strangely declared, but that it is, in the view of the Hindu, most sacred in its claims" and "that it is not a mere civil distinction, but emphatically religious" (Roberts 1847, 16, v). The Madras Missionary Conference perhaps put it most clearly in its declaration of 1850 , which concluded decades of dispute about the status of caste:

Caste, which is a distinction among the Hindoos, founded upon supposed birth-purity and impurity, is in its nature essentially a religious institution, and not a mere civil distinction. The Institutes of Menu and other Shastras regard the division of the people into four castes, as of Divine appointment. We find, also, that stringent laws were enacted for upholding this important part of the Hindoo religion. Future rewards are decreed to those who retain it, and future punishments to those who violate it. The Hindoos of the present day believe, that the preservation - or loss of caste deeply affects their future destiny. (Cited in Meigs 1854, 471; emphasis added)

Here, we see once again how the conclusion that caste was a religious institution implied that it revolved around a system of stringent laws falsely believed to be of "divine origin." This entire system decreed future rewards to those who obey its rules and future punishment to those who do not. Thus, the Protestants' postulation of a religious-cum-civil system of laws at the heart of Hindu society allowed the elements of earlier European descriptions of caste to coalesce into one coherent Gestalt.

\section{Caste and Hinduism}

Throughout the nineteenth century, missionaries and other authors stated that caste was not only inseparably connected to Hinduism but also formed its core structure. This claim addressed a persistent problem in the Western understanding of Indian culture and society: the religion of the Hindus seemed to be an incoherent amalgamation of all kinds of doctrines, traditions, practices, texts, 
myths, and groups, without any shared creed, sacred text, or religious authority. How could it then be a religion at all? 3

Scholars did not raise this question as a challenge to the dominant European understanding of Indian culture and society. In fact, they did not even contemplate the possibility that the incoherent and chaotic appearance of "Hinduism" was a problem internal to the structure of their experience and theorizing. Closer studies of Indian society kept generating anomalies that put into disarray the account of the "heathen" people of India as a nation of castes united by a common religion. However, instead of realizing that these were problems internal to the European account of Hinduism, Western scholars engaged in a protective move: they externalized this disorder as a characteristic property of the religion in question. Over the decades, they began to characterize Hinduism as "a chaos," "a jungle" or a "banyan tree," which nevertheless formed the religion of the Hindus (see De Roover and Claerhout 2010).

Of course, this generated another question. How could a religion whose main characteristic appeared to be disorder survive and retain its followers? Surely, it would have to fall apart. Yet, Hinduism had survived for centuries if not millennia. Given its apparent lack of structure, what kept this religion together and prevented it from falling apart? This issue was of particular importance to Christian missionaries in India, since they professed the aim of breaking the hold of false religion. Consider a discussion on caste that occurred among the missionaries and converts of the Free Church of Scotland in Madras in November 1845. The diversity of groups in Indian society, they stated, had made it seem as though the Indian people did not have one religion but was divided into "so many religious sects and subdivisions, which divide families and tribes from one another." Yet there was unity behind this diversity. Indeed, the Hindus did not worship one God or one common Lord, but "on the other hand, Caste is a thing which is common and sacred to them all" (in Roberts 1847, 1212). In other words, in caste, the missionaries claimed to have found the common system that held the nation and religion of the Hindus together.

The discussion in Madras had started by putting the following question to native converts: "Is Caste inseparably connected with Hinduism, or is it not?" The neophytes dutifully gave the answers the missionaries had taught them. Again and again, it was repeated that caste is not simply connected to Hinduism but that "Caste is nothing but Hinduism itself" (in Roberts 1847, 121). One convert said that both the sacred texts and the everyday notions of caste that a Hindu receives from his parents left no doubt "that Caste and religion are synonymous." This unity between caste and religion derived

\footnotetext{
${ }^{3}$ Such comments about the chaotic nature of Hinduism would return again and again from the eighteenth to the twentieth century: for instance, see Harcourt 1924, 28; Lyall 1884, 1-2; Orme 1805, 437; Strachey 1911, 315-7; Whitehead 1924, 4; Wilson 1862, 1.
} 
from the fact that the institutes of Manu and other standards of the Hindu religion claim that both "have sprung from one and the same source, the mind of the Supreme Being" (in Roberts 1847, 66-8).

Another convert looked at "the facts." From the fact that caste is considered divine in its origin and that its main aim is to teach how "to regulate the conduct towards the gods, with reference to future births and final absorption," he inferred the following conclusion: "Caste is now so inseparably part of the Hindu system, that any attempt to sever it from what is considered religious, would be to render Hinduism, as it now exists, a mass of confusion" (in Roberts 1847, 8081). Yet another witness summed things up in a metaphor:

Who ever thought of separating Caste from Hinduism, or Hinduism from Caste? They are so joined together, that the life of the one depends on the life of the other, and the death of the one on the death of the other. You have all seen on the hedges a plant so twisted round another as to be wholly supported by it, so that both seemed to be one tree. If you separate the one from the other, it will be like a reed shaken with the wind. So, if you separate Caste from Hinduism, it will come to nothing. (In Roberts 1847, 110)

The followers of Hinduism had nothing in common except the system of caste; therefore, this religion would dissolve without this core structure. This "discovery" instantiated the same kind of cognitive move that European scholars of Indian culture had engaged in before. The idea that caste was the sacred institution at the heart of Hindu religion had brought internal order to the European experience and understanding of Indian culture. However, this was again externalized as though it concerned a structural property of the alleged religion and social system of the Hindus.

In the dominant discourse, caste had now become the structure that held Hinduism together. As one author put it: because of the divine origin that the Hindus attributed to caste, this system could form the cement of the fabric of the Hindu religion, which pervaded and closely bound the whole (Duff 1840, 616-7). In other words, once Europeans had attributed this status to caste, this enabled them to see "the Hindu religion" and "its caste system" as a coherent whole. Seemingly, they could now fit any factual finding or textual passage into this well-cemented building, which held together their understanding and experience of Indian society.

\section{The Moral Structure}

How could the Protestants' conclusion that caste was religious have this kind of impact? I do not have any conclusive answers to give here, but we can take some tentative steps. From a Christian perspective, the distinction between a religious and a civil institution revolves around the fact that the former has to be of divine origin and embody the purpose of God, whereas the latter is merely a 
human creation. Thus, Catholicism views the Church as a religious institution, simultaneously divine and human. Even though manned by human beings, the Church has to represent the purpose of God on earth; therefore, its laws count as religious obligations. ${ }^{4}$ Similarly, the Jews hold that the Mosaic law is a revelation from God: the rules of the covenant state His expectations towards the nation of Israel and these include regulations as to the institutions and practices of everyday life.

These claims about religious institutions and the distinction between religious and civil law had known a long history in Christianity but they gained particular importance during the Protestant Reformation. Reformers like Luther and Calvin argued that the authority of human legal institutions could only be civil or political and never religious. Canon law, according to them, was a system of human law falsely presented as religious by claiming divine sanction. The Church and its clerical hierarchy did not represent God's purpose on earth but it was a purely human institution that falsely presents itself as religious and imposes its fabrications onto the believers in the name of God's will (see De Roover 2015, 86-137).

The Reformation also reinforced a similar argument about Judaism. While God had indeed revealed himself to Moses at Mount Sinai, Christian theologians argued, the first covenant of law had been abrogated by the Gospel and its covenant of grace and freedom. This implied that the continued existence of rabbinic Judaism involves a similar deception as that inflicted by the papacy. To trick the believers into a human bondage of law and external ceremonies, the Jewish priesthood continued to present the laws and customs of the nation of Israel as divine commandments, even though they had lost this religious status and become purely civil or political in nature.

From the Protestant perspective, if caste was an institution of false religion, it would have to function in a similar way. That is, the Hindu religion would enforce the civil laws of caste by falsely claiming that the system is rooted in divine revelation. This ploy gave caste its deceptive strength and allowed the system to reproduce itself in spite of the immorality of its injunctions. The perpetrators of the ploy could not but be a class of cunning clerics. They deceived the Hindus into believing that strict obedience to the laws of caste is essential to religion and to the rewards of this and the future life. In this picture of Hinduism, divine worship involves abiding by the religious obligations of caste, while violating these obligations results in excommunication from the system of Hindu society (and inferior rebirth for one's soul). What makes the Hindus so blind to the iniquity of the laws of caste, according to the same picture, is the superstitious awe continuously reinforced by the Brahmins to

\footnotetext{
${ }^{4}$ Catechism of the Catholic Church, $\mathbb{\$} 760, \mathbb{S} 778$;

URL: < http://www.vatican.va/archive/ENG0015/_P27.HTM>; consulted on 11 February 2015.
} 
deceive them into the delusion that caste laws constitute religious obligations. (Of course, this raises the question as to where these Brahmins get this extraordinary capacity to deceive ordinary believers.)

In this nineteenth-century account of caste and Hinduism, we see the original outlines of the peculiar moral structure that continues to be attributed to the caste system unto this day. Together, caste and Hinduism form a religious system that misleads the Hindus into following a set of immoral principles as the requirements of morality. In other words, the entire structure of today's dominant conception of "the caste system" derives from a Protestant-Christian account, which basically describes caste as an institution of false religion that deceptively merges civil laws with religious obligations.

If we were to discard the overtly biblical elements from the nineteenth-century missionary descriptions of Hinduism and caste, it would become difficult to distinguish them from the contemporary moral discourse. In its outlines, the basic message of anti-caste academics and activists corresponds largely to that propagated by Christian critics more than two hundred years ago. Others have noted how the Christian polemics against Judaism functioned as conceptual resources for the British conceptions of Hindu religion and society (Yelle 2013, 137-160). However, they ignore how these conceptual resources determined the basic immoral structure still attributed to the caste system today.

First, today's critics chastise the caste system for providing people with certain privileges and occupations according to the caste of their birth and thus imprisoning individuals in the social position in which they are born, no matter how talented they may be. Second, the system is accused of giving some castes a sense of inherent privilege and entitling them to control, discriminate, and humiliate these others. Third, it supposedly draws on religion to divide the Indian people into distinct groups separated by insurmountable barriers. Fourth, it dehumanizes the untouchable castes or Dalits by excluding them from all civilized social life and treating them like animals or worse. Together, these aspects are said to make the caste system "one of the most brutal modes of hierarchical social organisation that human society has known" (Roy 2014). ${ }^{5}$

The original religious core driving such judgements becomes visible when we remember that they were aimed not only at Hinduism but also at Catholicism and Judaism. That is, these criticisms of "the caste system" result from conceptualizing it as a structural variant of the institutions of the

\footnotetext{
${ }^{5}$ For some recent instances of this moral discourse about the caste system, see Guru (2016), Jadhav (2005), Teltumbde (2015), and the debates in a Subcommittee of the United States Congress: India's Unfinished Agenda: Equality and Justice for 200 Million Victims of the Caste System, Hearing before the Subcommittee on Africa, Global Human Rights and International Operations of the Committee on International Relations House of Representatives, One Hundred Ninth Congress, First Session (October 6, 2005), 10-11, 14, 16-18, 29-31.
} 
latter two religions. In fact, most of the major criticisms of caste can be traced back to a contrast made by Protestant Christianity between the state of society under true religion and that of societies under the rule of "false religion" and its "bondage of law." Unlike its corrupt rivals, Protestants said, true religion does not allow for divinely appointed classes of people with certain privileges supposedly granted to them by God. Under the Gospel, distinctions of rank and all other human institutions and laws are merely civil and never religious. Hence, any person could rise (or descend) from one rank to another, regardless the accidents of birth. In contrast, corrupt religion cuts up the community of believers into classes of people by birth and divine appointment and thus creates insurmountable barriers (Anonymous 1818; Roberts 1847, 4-5).

\section{Conclusion}

What is today presented as an analysis based on human rights and principles of equality started out very differently. The entire discourse relied on clusters of theological background ideas about the relationship between Christianity and Judaism, the New and the Old Testament, the nature of priesthood, the separation of civil law from religious obligation, and the status of social distinctions in relation to religion. In turn, these clusters were embedded in a much larger framework that had emerged out of the Reformation and its interpretations of the Bible. More than being a set of explicit ideas only, this framework consists of implicit conceptual resources that have allowed Europeans to make sense of the popular descriptions about religion and caste in India.

How is all of this possible? Most of today's authors writing about the caste system know next to nothing about these centuries-old intra-Christian debates. Yet, academics, activists, and journalists keep drawing upon descriptions that derive from concerns and concepts internal to these debates. They would not accept that the Hindu people is a variant of the biblical nation of Israel, that Christianity superseded Judaism, or that the Brahmins are a hybrid of the Jewish tribe of the priesthood and the Catholic clergy. Probably, many of them would not even agree that the caste system is a religious institution that deceives people into embracing human-made laws as though these are divine commandments. Still, their conceptual vocabulary indicates that they implicitly accept the truth of such theological claims.

The apparent implausibility of this conclusion indicates that much more research is needed to strengthen this hypothesis about the emergence of the conceptual entity called "the caste system." Yet it also indicates how promising this research is: however tentative and incomplete the two proposed hypotheses may be, they succeed at generating new questions that need answering.

Consider the fact that the early modern Christian conceptions of the biblical nation of Israel turn out to be central to the dominant European descriptions of the people and culture of India. How is this possible? Two sub-questions are involved here. The first concerns the ubiquity of this 
interpretation of the Old Testament among the educated classes of early modern Europe. Travellers like Della Valle, Orientalists like De la Crequinière and Halhed, missionaries like De Nobili, Rogerius, and Ward, and colonial officials like Orme, Scrafton, and Grant - all of them drew upon this account when they described the religion and social life of India. This means that the Christian conception of the ancient Jews must have been part and parcel of their cognitive world. Its terms of description were readily available to them as conceptual resources that helped them to understand other cultures. From recent studies, we know that certain ideas about the biblical nation of Israel had become widely present in the political thinking of seventeenth-century Europe (Nelson 2010; Sutcliffe 2003). But how exactly could such ideas about the Old Testament Jews become central to the cognitive world of such different types of Europeans?

The second question concerns the fact that modern Europeans viewed the "heathens" of India as a variant of this ancient nation of Israel. How could it make sense to see an alien people found on the Indian subcontinent as a variant of the Jews who had lived in the Middle East more than 1,500 years before? Facile explanations are at hand here. Some scholars, for instance, may insist that certain aspects of Hinduism indeed look similar to Judaism. But then such similarities are apparent only because a particular background framework shapes the available descriptions of both "religions." So the question becomes: how did this background framework give shape to the dominant discourse about Hinduism and the caste system? Here, we need a closer study of the different elements in the emergence of the early modern European account of the Old Testament Jews. We also need to examine their transformation into the conceptual resources used by European culture to make sense of alien peoples and societies.

There are more implications. The basic nineteenth-century description of the caste system integrated earlier theological ideas into one coherent whole: a system that merged civil and religious law by ascribing a divine origin to both. Initially, this diagnosis was specific to Protestant analyses but it soon appeared in the most popular geographical and historical works of Western Europe, written by authors with a variety of religious and philosophical backgrounds. Without even referring to the biblical account of the nation of Israel or the Protestant objections to the Catholic Church, these authors told stories about India that presupposed elements from both theological accounts. What cognitive resources must have been present among their readership in Europe to allow for this? How could the concern about the relationship between religious and civil law resonate among so many authors and their readers? What does this tell us about the dynamics shaping the development of European societies during this era? Since today's Western scholars and their readers continue to buy into the same story about "Hinduism" and "the caste system," the scope of this question is even wider. How is it possible that people still continue to reproduce an inherently implausible account of 
Indian society, even though they are ignorant of the Christian concerns and conceptual schemes that held together this account?

The situation becomes all the more puzzling when we turn to the Indian debates on the caste system. These also presuppose the existence of a social organization that deceives the Hindus into living by a set of immoral injunctions disguised as moral obligations. Thus, they also rely on elements from the Protestant consensus about "the Hindu system." Yet, Indian academics and activists do not belong to a culture constituted by centuries of Christian religious dynamics. They cannot possibly share the background framework that allowed the Western educated public to make sense of such descriptions of Indian culture. For instance, the concepts and concerns related to the relationship between Christianity and Judaism or that between Protestantism and Catholicism must be alien here. Nonetheless, educated Indians reproduce "critical" descriptions that emerged from mapping "the caste system" onto these concepts and concerns. This has been going on for over two centuries and even led to laws enacted by the Indian authorities. Did this conception of the caste system then really find roots in the cognitive world of a very different culture? How could it do so? That is, how are these descriptions of caste understood by the Indian intelligentsia, given that the conceptual resources needed to make sense of them must be missing here?

These are all questions for future research. They are significant not only as theoretical concerns but also because of their practical consequences. The moral discourse about caste was part of an attempt by Christian missionaries and colonial officials to remedy situations in Indian society, which they perceived as unjust and inhumane. When Indians adopted this discourse, this was often part of their effort to address problems of injustice and oppression in their society. Today, we are in the privileged position of pointing out the flaws in these past attempts. We realize that the dominant conceptual language does not help us in formulating the problems of Indian society, let alone in solving them. However, with the privilege comes a responsibility: that of identifying the flaws in the current conception of the caste system in such a way that future generations will be able to go beyond these and develop better descriptions and diagnoses of these problems. 


\section{References}

Adam, William. 1824. Correspondence Relative to the Prospects of Christianity: and the means of promoting its reception in India. Cambridge: The University Press.

Anonymous. 1800. "The History of British India," in The Asiatic Annual Register...For the Year 1799, 182. London.

Anonymous. 1803. "Account of Books: On the Religion and Literature of the Burmans by Francis Buchanan," in The Asiatic Annual Register...For the Year 1802, 23-33. London.

Anonymous. 1818. "The Four Castes of the Hindoos." Missionary Papers for the Use of the Weekly and Monthly Contributors to the Church Missionary Society, 9 (Michaelmas, 1818).

Balagangadhara, S. N. 1994. "The Heathen in His Blindness ...": Asia, the West, and the Dynamic of Religion. Leiden: Brill.

. 2012. Reconceptualizing India Studies. New Delhi: Oxford University Press.

. 2014. "On the Dark Side of the 'Secular': Is the Religious-Secular Distinction a Binary?” Numen: International Review for the History of Religions, 61(1): 33-52.

Bernier, François. 1671. Suite des Mémoires du Sieur Bernier, sur l'Empire du Grand Mogol. La Haye.

Blount, Charles. n.d. Anima Mundi: Or, An Historical Narration of the Opinions of the Ancients Concerning Mans Soul After this Life. Amsterdam.

Blunt, Edward A.H. 1931. The Caste System of North India, with special reference to the United Provinces of Agra and Oudh. Madras: Oxford University Press.

Bolingbroke, Henry St. John Lord Viscount. 1777. The Works of the late Right Honorable Henry St. John, Lord Viscount Bolingbroke, vol. 5. Edited by David Mallet. London.

Brookes, Richard. 1820. The General Gazetteer; or, Compendious Geographical Dictionary. London.

Brucker, Joseph. 1910. "Malabar Rites." In The Catholic Encyclopedia, 558-562. New York: Robert Appleton Company.

Chahal, Chanan. 2008. The Evil of Caste: The Caste System as the Largest Systemic Violation of Human Rights in Today's World. London: The Federation of Ambedkarite and Buddhist Organisations UK and Dalit Solidarity Network UK.

Craufurd, Quintin. 1790. Sketches Chiefly Relating to the History, Religion, Learning, and Manners of the Hindoos. London.

Deloche, Jean. 1971. Voyage en Inde du Comte de Modave, 1773-1776. Paris: École Française d'ExtrêmeOrient.

De Nobili, Roberto. 2000. Report Concerning Certain Customs of the Indian Nation, in: Preaching Wisdom to the Wise: Three Treatises by Roberto de Nobili, S.J., Missionary and Scholar in $17^{\text {th }}$ Century India, ed. Anand Amaladass and Francis X. Clooney. St. Louis: The Institute of Jesuit Sources. 
De Roover, Jakob. 2015. Europe, India, and the Limits of Secularism. New Delhi: Oxford University Press. De Roover, Jakob and Sarah Claerhout. 2010. “The Colonial Construction of What?” In Rethinking Religion in India: The Colonial Construction of Hinduism, ed. Esther Bloch, Marianne Keppens and Rajaram Hegde, 164-183. London and New York: Routledge.

De Roover, Jakob and Sarah Claerhout. 2015. "The Caste Connection: On the Sacred Foundations of Social Hierarchy." Theatrum Historiae, 17: 9-36.

Dirks, Nicholas B. 2002. Castes of Mind: Colonialism and the Making of Modern India. Delhi: Permanent Black.

Dubois, Jean Antoine. 1817. Description of the Character, Manners, and Customs of the People of India; and of Their Institutions, Religious and Civil. London.

Dubois, Abbé Jean Antoine. 1906. Hindu Manners, Customs and Ceremonies, trans. Henry Beauchamp.

Oxford: Clarendon Press.

Duff, Alexander. 1840. India and India Missions: Including Sketches of the Gigantic System of Hinduism, Both in Theory and Practice. Edinburgh.

Elwell, W. A and B. J. Beitzel. 1988. "Covenant." In Baker encyclopedia of the Bible, 533-534. Grand Rapids, MI: Baker Book House.

Emery, A. C. 2003. "Hēērem." In Dictionary of the Old Testament: Pentateuch. Downers Grove, IL: InterVarsity Press.

Falk, Gerhard. 1992. The Jew in Christian Theology. Jefferson, NC and London: McFarland \& Company. Forbes, James. 1805. Reflections on the Character of the Hindoos; and on the Importance of Converting Them to Christianity. London.

Forrester, Duncan B. 1980. Caste and Christianity: Attitudes and Policies on Caste of Anglo-Saxon Protestant Missionaries in India. London and Dublin: Curzon.

Forster, Georg. 1785. Sketches of the Mythology and Customs of the Hindoos. London.

Gelders, Raf and Willem Derde. 2003. "Mantras of Anti-Brahminism: Colonial Experience of Indian Intellectuals." Economic and Political Weekly, 38 (43): 4611-4617.

Gelders, Raf. 2009. "Genealogy of Colonial Discourse: Hindu Traditions and the Limits of European Representation." Comparative Studies in Society and History, 51 (3): 563-589.

Grant, Charles. 1813. "Observations on the State of Society among the Asiatic Subjects of Great Britain, particularly with respect to Morals; and on the means of improving it." In British Parliamentary Papers - Papers Relating to East India Affairs, 1812-1813.

Grey, Edward (ed.). 1892. The Travels of Pietro Della Valle in India: From the Old English Translation of 1664 by G. Havers. London: Printed for the Hakluyt Society. 
Guru, Gopal. 2016. “A Tragic Exit From Social Death.” Outlook, 1 February 2016, Web Extra. URL: <http://www.outlookindia.com/magazine/story/a-tragic-exit-from-social-death/296480> Guthrie, William. 1782. A New Geographical, Historical, and Commercial Grammar; and Present State of Several Kingdoms of the World. London.

Halhed, Nathaniel B. 1776. A Code of Gentoo Laws, or, Ordinations of the Pundits, from a Persian Translation, Made from the Original, Written in the Shanscrit Language. London.

Harcourt, H. 1924. Sidelights on the Crisis in India: Being the Letters of an Indian Civilian and Some Replies of an Indian Friend. London: Longmans, Green and Co.

Harvard, W.M. 1823. A Narrative of the Establishment and Progress of the Mission to Ceylon and India, founded by the Late Rev. Thomas Coke, L.L.D., under the direction of the Wesleyan-Methodist Conference. London. Herbert of Cherbury, Edward Lord. 1768. A Dialogue between a Tutor and His Pupil. London. Holwell, John Z. 1765. Interesting Historical Events Relative to the Provinces of Bengal, and the Empire of Indostan. London.

Hubbard, D. A. 1996. "Priests and Levites.” In New Bible Dictionary, ed. D. R. W. Wood, I. H. Marshall, A. R. Millard, J. I. Packer, and D. J. Wiseman, 961. Leicester, England; Downers Grove, IL: InterVarsity Press.

Hunt, Lynn A., Margaret C. Jacob and Wijnand Mijnhardt. 2010. The Book that Changed Europe: Picart \& Bernard's Religious Ceremonies of the World. Cambridge, MA: Harvard University Press.

Jacolliot, Louis. 1880. Les Législateurs Religieux: Moïse, Manou-Mahomet, Traditions Religieuses Comparées. Paris: Librairie Internationale.

Jadhav, Narendra. 2005. Untouchables: My Family's Triumphant Escape from India's Caste System. Berkeley and Los Angeles: University of California Press.

Jones, Sir William. 1796. "Institutes of Hindu Law or, the Ordinances of Menu." In Representing India: Indian Culture and Imperial Control in Eighteenth-Century British Orientalist Discourse, vol. 9, ed. Michael J. Franklin. London and New York: Routledge, 2000.

Karesh, Sara E. and Mitchell M. Hurvitz. 2003. Encyclopedia of Judaism. New York: Facts On File. Kaye, John William. 1859. Christianity in India: An Historical Narrative. London: Smith, Elder and Co. Klostermaier, Klaus K. 2007. A Survey of Hinduism. Albany: State University of New York Press. La Crequinière. 1705. The Agreement of the Customs of the East-Indians, With those of the Jews, and other Ancient People. London.

Landmann, George. 1835. A Universal Gazetteer; Or, Geographical Dictionary of the World. London. Lord, Henry. 1630. A display of two forraigne sects in the East Indies. London.

Lyall, Alfred. 1884. Asiatic Studies: Religious and Social. London: John Murray. 
Marshall, John. 1840. Brookes's Universal Gazetteer, Re-Modelled and Brought Down to the Present Time.

Philadelphia.

Martin, Benjamin. 1769. Physico-Geology: or, a New System of Philosophical Geography. London.

Maurice, Thomas. 1800. Indian Antiquities or Dissertations, relative to ... Hindostan, vol. 4. London.

McCready, W. O. 1979-1988. "Priests And Levites." In The International Standard Bible Encyclopedia,

Revised, vol. 3, ed. G. W. Bromiley, 965. Grand Rapids: William B. Eerdmans.

Meigs, Benjamin C. 1854. Caste, in the Island of Ceylon. Boston.

Nelson, Eric. 2010. The Hebrew Republic: Jewish Sources and the Transformation of European Political Thought.

Cambridge, MA: Harvard University Press.

Orme, Robert. 1753. "General Idea of the Government and People of Indostan." In: Historical Fragments of the Mogul Empire, of the Morattoes, and of the English Concerns in Indostan. London, 1805.

Orme, Robert. 1763. A History of the Military Transactions of the British Nation in Hindostan from the Year 1745, To Which is Prefixed a Dissertation on the Establishment made by Mahomedan Conquerors in Indostan, Vol. 1. London.

Orme, Robert. 1805. Historical Fragments of the Mogul Empire, of the Morattoes, and of the English Concerns in Indostan. London.

Pearson, Hugh. 1817. Memoirs of the Life and Writings of the Rev. Claudius Buchanan. Philadelphia:

Benjamin \& Thomas Kite.

Rao, Anupama. 2010. The Caste Question: Dalits and the Politics of Modern India. New Delhi: Permanent Black.

Roberts, Joseph (ed.). 1847. Caste, in Its Religious and Civil Character, Opposed to Christianity: Being a Series of Documents by the Right Reverend Bishops Heber, Wilson, Corrie, and Spencer, and by Eminent Ministers of

Other Denominations. London: Longman, Brown, Green, and Longmans.

Roy, Arundathi. 2014. “India's Shame.” In: Prospect, December 2014.

Rehm, M. D. 1992. "Levites and Priests." In The Anchor Yale Bible Dictionary, vol. 4, ed. D. N. Freedman, 305. New York: Doubleday.

Ridge, D. R. 2003. "Excommunication.” In Holman Illustrated Bible Dictionary, ed. C. Brand, C. Draper, A. England, S. Bond, E.R. Clendenen, and T.C. Butler, 521. Nashville, TN: Holman Bible Publishers. Rogerius, Abraham. 1651. De Open-Deure Tot het Verborgen Heydendom, Ofte Waerachtigh vertoogh van het Leven ende Zeden; mitsgaders de Religie, ende Gods-dienst der Bramines, op de Cust Chormandel, ende de Landen daar omtrent. Leyden.

Rubiés, Joan-Pau. 2002. Travel and Ethnology in the Renaissance: South India through European Eyes, 12501625. Cambridge: Cambridge University Press. 
Scrafton, Luke. 1761. Reflections on the Government of Indostan and A Short Sketch of the History of Bengal. Edinburgh.

Silva, M. and M. C. Tenney. 2009. "Excommunication." In The Zondervan Encyclopedia of the Bible, D-G, 458. Grand Rapids, MI: The Zondervan Corporation.

Staughton, William. 1811. The Baptist Mission in India: Containing a Narrative of Its Rise, Progress, and Present Condition, a Statement of the Physical and Moral Character of the Hindoos, Their Cruelties, Tortures and Burnings, With a Very Interesting Description of Bengal, Intended to animate to Missionary co-operation. Philadelphia.

Strachey, John. 1911. India: Its Administration \& Progress. London: Macmillan.

Stuart, Charles. 1808. Vindication of the Hindoos from the Aspersions of the Reverend Claudius Buchanan. London.

Subrahmanyam, Sanjay. 2010. "Monsieur Picart and the Gentiles of India." In Bernard Picart and the First Global Vision of Religion, ed. Lynn Hunt, Margaret Jacob, and Wijnand Mijnhardt, 197-214. Los Angeles: Getty Research Institute.

Sutcliffe, Adam. 2003. Judaism and Enlightenment. Cambridge: Cambridge University Press.

Teltumbde, Anand. 2015. "Ghar Wapsi: Welcome to the Hellhole of Hinduism." Economic and Political Weekly, 50 (1): 10-11.

Trautmann, Thomas R. 1997. Aryans and British India. Berkeley, CA: University of California Press. Walker, John. 1795. The Universal Gazetteer. London.

Ward, William. 1822. A View of the History, Literature, and Mythology of the Hindoos; including a minute description of their manners and customs, and translations from their principal works. London: Kingsbury, Parbury and Allen.

Whitehead, Henry. 1924. Indian Problems in Religion, Education, Politics. London: Constable \& Co. Wilkins, John. 1678. Of the Principles and Duties of Natural Religion Two Books. London.

Wilson, Horace Hayman. 1862. Works by the Late Horace Hayman Wilson, vol. 1. London: Trübner \& Co. Yelle, Robert A. 2013. The Language of Disenchantment: Protestant Literalism and Colonial Discourse in British India. New York: Oxford University Press.

Zastoupil, Lynn and Martin Moir. 1999. "Introduction." In The Great Indian Education Debate: Documents Relating to the Orientalist-Anglicist Controversy, 1781-1843, ed. Lynn Zastoupil and Martin Moir, 1-72. Richmond: Curzon. 